\title{
Validation of the Hybrid Flowering Cherry Prunus Xincam (Rosaceae)
}

\author{
Richard T. Olsen and Alan T. Whittemore \\ U.S. National Arboretum, 3501 New York Ave. NE, Washington, D.C. 20002-1958, U.S.A. \\ Richard.Olsen@ars.usda.gov; Alan.Whittemore@ars.usda.gov
}

Abstract. The name Prunus $\times$ incam Ingram ex $\mathrm{R}$. Olsen \& Whittemore is validated here. Introduced as a cultivated variety in 1947, Ingram's name Prunus Xincam has been in use as a nomen nudum in horticultural literature and the nursery trade for artificial crosses involving the parent taxa $P$. incisa Thunberg $\times P$. campanulata Maximowicz. Prunus Xincam is an early flowering tree with two or three flowers in each persistent involucre, spreading sepals, and pink, deeply emarginate petals. Ingram's original introduction, the cultivated variety 'Okamé,' is the most widely grown form.

Key words: Okamé cherry, Prunus, Rosaceae.

Prunus L. (Rosaceae Jussieu), with some 200 species, is a ubiquitous component of the cultivated flora in temperate zones, including species that are important as fruit, nut, and ornamental crops. The most important group of ornamentals in the genus are the flowering cherries of Prunus subg. Cerasus (Miller) Focke sect. Pseudocerasus Koehne, a group of small trees from eastern Asia with very showy white or pink flowers (Rehder, 1940).

The Chinese species Prunus campanulata Maximowicz historically has attracted the attention of horticulturists because of its early flowering (early to mid-March) and the striking deep pink coloration of its petals. However, $P$. campanulata is a species of southern China, Taiwan, and possibly also the Ryukyu Islands of Japan, although the species may have been introduced here by man (Ohwi et al., 1984; Li \& Bartholomew, 2003). Its use in temperate climates is limited by its sensitivity to winter cold, since it can only be relied upon to survive winters in U.S. Department of Agriculture (USDA) hardiness zones 8 (annual minimum temperatures above $-12^{\circ} \mathrm{C}$ ) and warmer (Cathey, 1990).

Plants combining desirable characteristics of Prunus campanulata with greater cold tolerance have been produced by crossing $P$. campanulata with $P$. incisa Thunberg, the Fuji cherry, a more cold-tolerant species. Prunus incisa is native to Japan in central Honshu on the slopes of Mt. Fuji, Mt. Hakone, and Mt. Yatsu, and through the Southern Alps (Flower Association of Japan, 1982; Ohwi et al., 1984). It is one of the alpine cherries surviving to zone $5\left(-28^{\circ} \mathrm{C}\right)$ that flowers in early April in the north temperate zone (Ingram, 1948; Dirr, 1998; Kuitert \& Peterse, 1999). The hybrid was first produced ca. 1942 by English breeder Collingwood Ingram, who pollinated $P$. incisa stigmas with pollen collected from $P$. campanulata growing in the temperate house of the Royal Botanic Gardens, Kew (Ingram, 1942, 1948, 1970).

Ingram presented his best Prunus incisa $\times P$. campanulata hybrid to the Royal Horticultural Society on April 15, 1947, reported first as $P$. incisa $\times$ campanulata var. Okamé by the Gardeners' Chronicle (1947), but recorded by the Royal Horticultural Society, which conferred the plant an Award of Merit as Prunus $\times$ Incam var. 'Okamé' (Royal Horticultural Society, 1947a, b). The cultivar, and hybrid epithet, quickly became established in the British horticultural trade, receiving an Award of Garden Merit from the Royal Horticultural Society for its outstanding performance in British gardens only seven years after introduction (Fletcher, 1954). The plant was introduced to the United States before its public release, when American horticulturist Henry Skinner brought plants directly from Ingram's garden to the Morris Arboretum, University of Pennsylvania, in 1946 (Meyer \& Lewandowski, 1985). Further introductions into the United States and other countries have made this plant widely available in the international horticultural trade. Currently, P. Xincam 'Okamé' is a popular, widely used cultivar in temperate areas throughout the world with annual minimum temperatures above $-23^{\circ} \mathrm{C}$ (USDA hardiness zone 6). Recently, additional $P$. Xincam cultivars (e.g., 'Dream Catcher' and 'First Lady') have entered the trade (Pooler, 2007).

Although the name Prunus $\times$ incam is used widely in horticultural literature, nursery catalogs, and other garden-related publications, this binominal has never been validly published. Some publications (e.g., Huxley \& Griffiths, 1992) dropped the epithet, using only the cultivar name with the genus (e.g., Prunus 'Okamé'), but this has not slowed the use of the epithet in the nursery trade. The introduction of a variant spelling, Prunus $\times$ incamp, in England by Boddy (1964) and its use by the Flower Association of Japan (1982) and a few American horticulturists (Dirr, 1998, 2000) has introduced further confusion, with both spellings currently used commonly in the trade. 


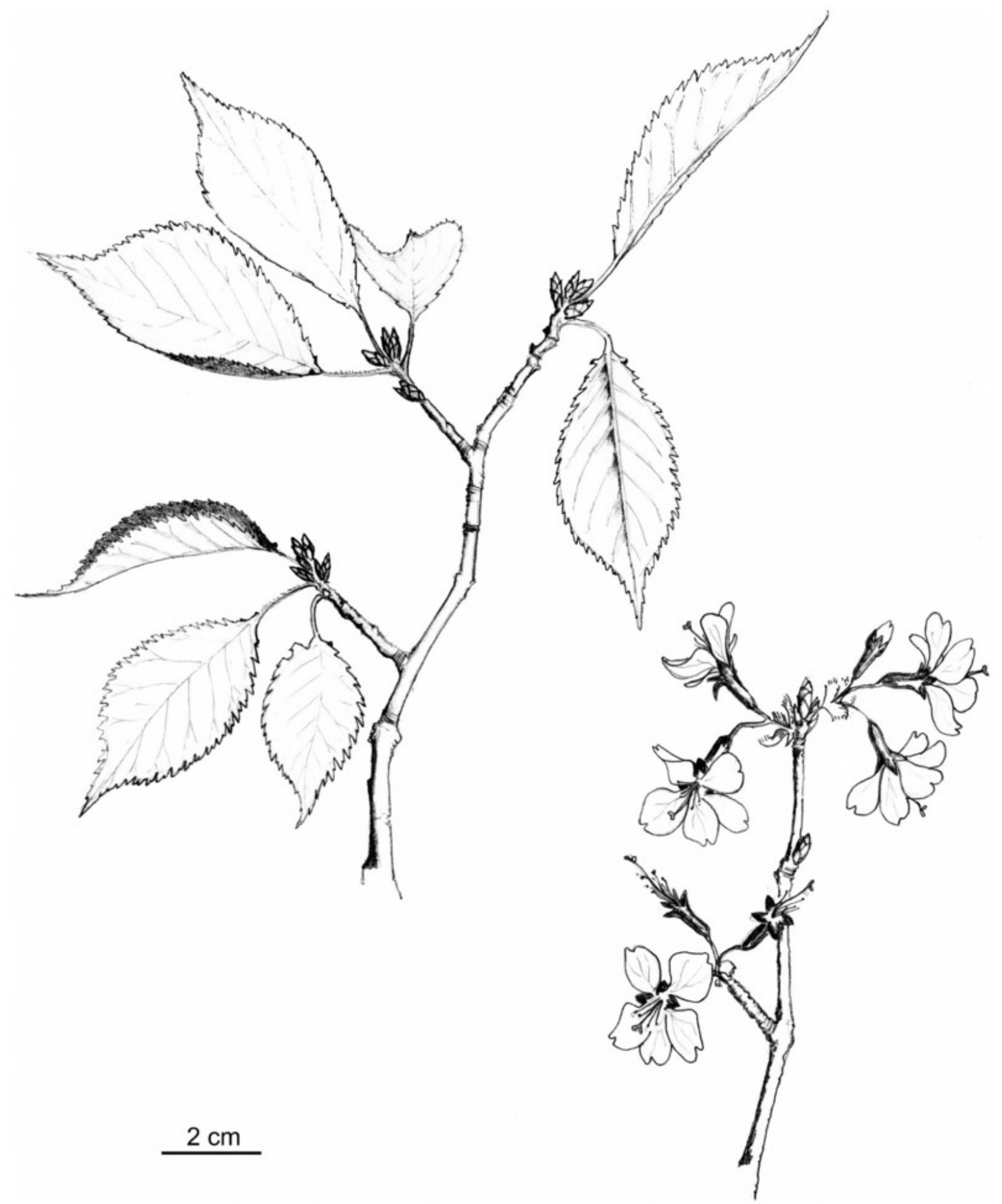

Figure 1. Prunus $\times$ incam Ingram ex R. Olsen \& Whittemore. Flowering and fruiting branches. Drawn by R. Olsen from living material of $P$. Xincam 'Okamé' (NA 18355-CL) at the U.S. National Arboretum.

In view of the continued widespread use of Prunus Xincam, and in view of the growing confusion caused by the existence of two well-established variant spellings, it seems appropriate to stabilize the name and its usage by formally publishing it and assigning a type specimen.

Prumus $\times$ incam Ingram ex R. Olsen \& Whittemore, nothosp. nov. [o Prunus incisa Thunberg $\times \mathrm{O}^{\circ}$ Prunus campanulata Maximowicz]. TYPE:
U.S.A. Washington, D.C.: United States National Arboretum, N side of Crabapple Collection, E of Beechwood Pond, planted tree in mowed meadow, accession NA 18355-CL, $38^{\circ} 54^{\prime} 37^{\prime \prime} \mathrm{N}$, $76^{\circ} 57^{\prime} 38^{\prime \prime} \mathrm{W}, 6 \mathrm{~m}, 22$ Mar. 2007, A. T. Whittemore \& R. Olsen 07-002 (holotype, NA; isotypes, A, K, MO, MOR, TUS). Figure 1.

Arbor praecox; ramuli hornotini glabri; gemmae 1 ad 3 in quaque axilla. Folia margine argute serrata. Flores 2 ad 3 
involucro communi cincti. Sepala patula, $2-3 \mathrm{~mm}$ longa; petala carnea, emarginata, ca. $9 \mathrm{~mm}$ longa.

Deciduous trees to $8 \mathrm{~m}$ tall; bark silvery gray, smooth except for prominent transverse lenticels; young shoots glabrous; buds 1 to 3 per axil; stipules caducous. Petiole 7-12 mm, upper surface villous; glands none or 1 at summit of petiole; leaf blade narrowly obovate or oblanceolate, $47-70 \times 22$ $31 \mathrm{~mm}$, dark green, with 7 to 9 major veins on each side of the midrib, glabrous except for a few inconspicuous villous hairs on both surfaces of major veins and leaf margin, apex slenderly acuminate, base obtuse (seldom acute) or rounded, margins sharply serrate. Inflorescence appearing before expansion of leaves, of 2 or 3 flowers on 3 $13 \mathrm{~mm}$ pedicels, common peduncle absent or to $3 \mathrm{~mm}$; bracts to $5 \mathrm{~mm}$, several around base of inflorescence, outer bracts brown and scalelike, forming an involucre, inner bracts green, obovate, strongly toothed; involucre persistent in flower. Flower with petals pink, hypanthium and sepals red; hypanthium cylindrical, 5-8 8 2-3 mm, glabrous; sepals triangular, $2-3 \times 1.5-2 \mathrm{~mm}$, entire and glabrous, shorter than hypanthium and spreading perpendicular to it; petals oblong to obovate, deeply emarginate, ca. $9 \times 4-6 \mathrm{~mm}$; stamens 4 $7 \mathrm{~mm}$, anthers plump, pollen copious and wellformed; style projecting 6-11 mm beyond hypanthium. Fruit not seen, rarely produced.

Discussion. The type specimen came from a plant of Prunus Xincam 'Okamé' (NA 18355-CL) at the U.S. National Arboretum that traces back, via the Washington Park Arboretum in Seattle, Washington, to the original distribution of Ingram's cultivar by the Morris Arboretum. There seems to be no valid reason to replace the original, well-established spelling, "incam," for the later variant "incamp." It is appropriate to recognize Collingwood Ingram as the author of this epithet, since he was the first to apply the name to this plant (Royal Horticultural Society, 1947a). It is questionable whether Ingram originally intended "Incam" as the epithet of a Latin binomial. In the first publications where it appeared (Royal Horticultural Society, 1947a: 374, 1947b: lvi), Ingram may have intended "Incam" merely as a shorthand notation of parentage, combining a syllable from each of the parent species. However, $P$. incam does not fit the definition of a hybrid formula as given in Article 23.6d and H.10.3 of the International Code of Botanical Nomenclature (McNeill et al., 2006). Ingram (1970: 182, 193) casually referred to seedlings of $P$. incisa $\times P$. campanulata as the Incam grex. In the six decades that have passed since $P$. incam was first published, incam has come into common use as the Latin epithet for the hybrid $P$. incisa $\times P$. campanulata. Meyer et al. (1993) cited this taxon as $P$. $\times$ incam Fletcher, attributing it to H. R. Fletcher, the author of the 1954 article presenting plants that received awards from the Royal Horticultural Society that year (Fletcher, 1954). However, Fletcher's publication lacked Latin descriptions, so that the hybrid name was not validated in this publication. Meyer et al. may have overlooked several earlier articles on $P$. incisa $\times P$. campanulata hybrids (Ingram, 1942, 1948; Royal Horticultural Society, 1947a, b) and the first publication of $P$. incam (Royal Horticultural Society, 1947a).

Acknowledgments. The authors thank Don Voss, Paul R. Fantz, and Joseph R. Rohrer for reviewing the manuscript and making helpful suggestions and comments.

\section{Literature Cited}

Boddy, F. A. 1964. Contemporary cherries. Gard. Chron. 155: 516.

Cathey, H. M. (editor). 1990. USDA Plant Hardiness Zone Map. Misc. Publ. U.S.D.A. No. 1475. Available at: <http://www.usna.usda.gov/Hardzone/>, accessed 14 September 2009.

Dirr, M. A. 1998. Manual of Woody Landscape Plants: Their Identification, Ornamental Characteristics, Culture, Propagation and Uses. Stipes Publishing, Champaign, Illinois.

2. 2000. Early-flowering Japanese cherries set the stage for spring. Nursery Managem. Production 16(1): 20-21, 87-88.

Fletcher, H. R. 1954. Award of garden merit-LXXXVII. J. Roy. Hort. Soc. 79: 127-133.

Flower Association of Japan (compilers). 1982. Manual of Japanese Flowering Cherries. Flower Association of Japan, Tokyo.

Gardeners' Chronicle. 1947. Societies, Royal Horticultural Society, floral committee. Gard. Chron. 121: 151.

Huxley, A. J. \& M. Griffiths (editors). 1992. The New Royal Horticultural Society Dictionary of Gardening. Macmillan Press, London.

Ingram, C. 1942. Cherry hybrids. Gard. Chron. 112: 163. 1948. Ornamental Cherries. Country Life, London. 1970. A Garden of Memories. H. F. \& G. Witherby, London.

Kuitert, W. \& A. Peterse. 1999. Japanese Flowering Cherries. Timber Press, Portland.

Li, C-L. \& B. Bartholomew. 2003. Cerasus. Pp. 404-420 in Z. Y. Wu, P. H. Raven \& D. Y. Hong (editors), Flora of China, Vol. 9. Science Press, Beijing, and Missouri Botanical Garden Press, St. Louis.

MeNeill, J., F. R. Barrie, H. M. Burdet, V. Demoulin, D. L. Hawksworth, K. Marhold, D. H. Nicolson, J. Prado, P. C. Silva, J. E. Skog, J. H. Wiersema \& N. J. Turland (editors). 2006. International Code of Botanical Nomenclature (Vienna Code). Regnum Veg. 146.

Meyer, F. G., P. M. Mazzeo \& D. H. Voss. 1993. A catalog of cultivated woody plants of the southeastern United States. U.S.D.A. Natl. Arbor. Contrib. No. 7. 
Meyer, P. W. \& R. Lewandowski. 1985. The "Okame" cherry. Arnoldia 45(1): 23-24.

Ohwi, J., F. G. Meyer \& E. H. Walker. 1984. Prunus. Pp. 541-545 in Flora of Japan. Smithsonian Institution, Washington, D.C.

Pooler, M. 2007. "Dream Catcher" and "First Lady" flowering cherry. HortScience 42: 174-175.
Rehder, A. 1940. Manual of Cultivated Trees and Shrubs Hardy in North America Exclusive of the Subtropical and Warmer Temperate Regions, 2nd ed. Macmillan, New York. Royal Horticultural Society. 1947a. Awards to plants in 1947. J. Roy. Hort. Soc. 72: 373-374.

Royal Horticultural Society. 1947b. Floral committee B. J. Roy. Hort. Soc 72: lv-lvi. 


\section{$2 \mathrm{BHL}$ Biodiversity Heritage Library}

Olsen, Richard T and Whittemore, Alan T. 2009. "Validation of the Hybrid Flowering Cherry Prunus xincam (Rosaceae)." Novon a journal of botanical nomenclature from the Missouri Botanical Garden 19, 490-493.

View This Item Online: https://www.biodiversitylibrary.org/item/124658

Permalink: https://www.biodiversitylibrary.org/partpdf/121956

\section{Holding Institution}

Missouri Botanical Garden, Peter H. Raven Library

\section{Sponsored by}

Missouri Botanical Garden

\section{Copyright \& Reuse}

Copyright Status: Permission to digitize granted by rights holder Rights: https://www.biodiversitylibrary.org/permissions

This document was created from content at the Biodiversity Heritage Library, the world's largest open access digital library for biodiversity literature and archives. Visit BHL at https://www.biodiversitylibrary.org. 